THURSDAY, MAY 27, I920.

Editorial and Publishing Offices:

MACMILLAN \& CO., LTD.

ST. MARTIN'S STREET, LONDON, W.C.2.

Advertisements and business letters should be addressed to the Publishers.

Editorial communications to the Editor.

Telegraphic Address: PHUSIS, LONDON.

Telephone Number: GERRARD 8830.

\section{The University of London: A Great Opportunity.}

L AST week there was made public the details, L printed elsewhere in this issue, of the offer by the Government of a site for the University of London. The Government proposes to give to the University about $\mathrm{II} \frac{1}{2}$ acres behind the British Museum as a site for the University headquarters and for colleges and institutions connected with it, including King's College, the premises of which in the Strand have long been insufficient for the needs of the college. The Senate has referred the question to a committee the report of which will doubtless shortly be forthcoming.

None of Mr. Fisher's labours in the cause of university education-and they are many-will redound more to his credit than the attempt to provide the University of London with a home worthy of itself and of the capital city of the Empire. Since the reconstitution of the University as a teaching body in 1900 , a great deal has been done in the organisation of university teaching and research in London. The professors and teachers of the University include many most distinguished men of science and scholars, and in the number of students it easily takes the lead in Great Britain. In recent years the University has drawn students from all parts of the world, attracted by the unique advantages which London can offer by reason of the resources of its libraries and museums. The establishment in the heart of the City of the School of Oriental Studies, and the association of business men with the foundation of the scheme of degrees of commerce, show also that the University can, by recognising the needs of the commercial interests of the City, obtain their active assistance and support.

It cannot be gainsaid, however, that, in spite NO. 2639, VOL. IO5] of all that has been done, the University has as yet failed to justify the hopes of those who looked forward at its reconstitution to the creation of a great teaching university. We need not enter into a discussion of all the causes which have prevented or hindered the fulfilment of these hopes. Among them are the heterogeneous nature of the institutions-varying from colleges of the type of University and King's Colleges to polytechnic institutions-in which the teaching and research work are carried on, and the intricacy of its existing constitution.

But unquestionably the chief cause of the failure of the University to take the great place assigned to it has been the discrete nature of its component parts, the inaccessibility of its administrative headquarters, and the lack of a home or a quarter of its own to which one could point as the University. It is a commonplace that bricks and mortar do not make a university, but it is undoubtedly true that without a tangible symbol there can be no appeal to the sympathies or imagination of the public, and it is the absence of such a symbol which more than anything else has militated against an understanding of the work that the University has done and is doing. Until the University possesses a building indisputably its own and designed for its own purpose, and until the great incorporated colleges are brought together, there can be no hope of impressing the greatness of the University upon the public, or of overcoming the dissipation of energy which is now such a hindrance to its work.

The question is, of course, not a new one. Its importance has been appreciated for some time, and before the war there were negotiations in the air for the acquirement of a site in Bloomsbury. For various reasons these negotiations did not fructify, and it may be that the site then under consideration was inadequate and in other ways unsuitable. The objections offered to it are not, however, valid in the present case.

The site now offered is excellent in every respect. By reason of its proximity to Bedford College for Women and to University College, it is already the nucleus of the "University Quarter" desiderated by the Haldane Commission. It is sufficient in extent not only for the administrative headquarters, the University library, and King's College, but also for other colleges of the University which are outgrowing their accommodation; and it is capable of extension if still further accommodation is required. 
It is, what South Kensington is not, an easily accessible place, and yet is not too noisy for the purpose, and it will have the additional advantage of the near presence of our greatest library and museum. It is safe to say that there is at present no site in London comparable with it, and none so suitable is likely to be available for many years.

The only objection possessing any validity to the acceptance of the Government's offer is the financial one. This is, we admit, a serious question, and it would be foolish to minimise its importance. Hitherto both the University headquarters and King's College have been housed free by the Government. This arrangement will now come to an end, and it is obvious that the cost of covering the site with buildings that shall be worthy of London's University will be considerable. Mr. Fisher feels that in this the University can look with confidence to the generosity and public spirit which have always marked the citizens of London. We think he is right. We are convinced that, if proper efforts are made, enough and more than enough money will be forthcoming for the purpose. The results of the present Vice-Chancellor's appeal to the City in connection with the degrees of commerce of the Lniversity afford an index of the support that would be forthcoming from the City Companies and the great commercial houses if the sympathies and the co-operation of the commercial community were enlisted in the greater cause of the University as a whole. Private benefactors would be attracted to a bold and well-conceived plan of creating a great university quarter, and Londoners, if there were some outward and visible sign of the greatness of their University, would not be found wanting either in the civic pride or in the willingness to pay which is found in the provinces or in Continental cities.

We hope the University authorities will take their courage in both hands and go forward boldly. The reasons which forbid the Government from giving further assistance in these days may be regrettable, but they are easily intelligible. We are sure that if the University rises to the occasion neither this nor any future Government will be allowed to leave it to struggle unaided. We are equally sure that if counsels of timidity are allowed to prevail and this opportunity is lost the University will have forfeited irrevocably any claim on the public or the Government for support in the future.

$$
\text { No. } 2639 \text {, VOL. IO5] }
$$

\section{Manuals on Applied Chemistry.}

(I) Practical Leather Chemistry: A Handbook of Laboratory Notes and Methods for the Use of Students and Works Chemists. By Arthur Harvey. Pp. viii + 207. (London: Crosby Lockwood and Son, 1920.) Price $5_{5} s$. net.

(2) Chemistry for Textile Students: A Manual Suitable for Technical Students in the Textile and Dyeing Industries. By Barker North, assisted by Norman Bland. (Cambridge Technical Series.) Pp. viii +379. (Cambridge: At the University Press, 1920.) Price 3os. net.

(3) The Chemistry of Coal. By John Braithwaite Robertson. (Chemical Monographs.) Pp. viii + 96. (London: Gurney and Jackson, I9r9.) Price 3s. 6d. net.

(I) $\mathbf{M}^{\mathrm{R}}$. HARVEY'S handbook is intended I for the use of the works chemist in charge of the analytical and testing department of a tannery. It is an eminently practical work, well and clearly written with due regard to modern methods, and evidently based upon considerable personal experience. It presupposes that the user of the book has had not only a preliminary course of instruction in theoretical chemistry, but also the opportunity of a laboratory training in manipulation in qualitative and quantitative analysis. In these circumstances the book can be thoroughly recommended as an excellent vade mecum to the work of the chemical laboratory of a tannery, or to the student who intends ultimately to specialise on leather chemistry. It will be found to cover practically every problem that the works chemist of a tannery may have to face. The analytical methods described have been thoroughly tested, and are well adapted to practical conditions.

(2) The manual by Mr. Barker North and Mr. Norman Bland is a work of a very different class. It is essentially a text-book of the elementary chemistry of certain of the non-metallic elements and their compounds, together with a somewhat bald account of the chemistry of a few carbon derivatives. The section devoted to technical chemistry as applied to the textile industries occupies only some twenty-eight of the 379 pages of which the book consists. The authors are lecturers in chemistry to the evening classes of the Technical Colleges of Bradford and Huddersfield respectively, both important centres of the textile and dyeing industries, and their object, no doubt, is to attract students who are, or may be, engaged in these industries. In their preface they point out that whilst the cotton and woollen industries occupy most important positions 